DOI https://doi.org/10.30525/978-9934-588-79-2-1.15

\title{
РІШЕННЯ ЗАДАЧІ РЕКОНСТРУКЦІЇ ТА КЛАСИФІКАЦІЇ ЗОБРАЖЕННЯ В ПРОСТОРІ ПАРАМЕТРІВ ФУНКЦІЙ ЗАПІЗНЕННЯ НА ПРИКЛАДІ КЛАСИФІКАЦЇ̈ УЗ ЗОБРАЖЕНЬ НОРМА-ПАТОЛОГІЯ ПЕЧІНКИ
}

\author{
Настенко С. А. \\ кандидат технічних наук, доктор біологічних наук, \\ старший науковий співробітник кафедри біомедичної кібернетики \\ Національного технічного університету України \\ «Київський політехнічний інститут імені Ігоря Сікорського» \\ Павлов В. А. \\ кандидат технічних наук, \\ дочент кафедри біомедичної кібернетики \\ Національного технічного університету Украӥни \\ «Київський політехнічний інститут імені Ігоря Сікорського» \\ Грішко Д. Ю. \\ бакалавр комп'ютерних наук, \\ магістр кафедри біомедичної кібернетики \\ Національного технічного університету України \\ «Київський політехнічний інститут імені Ігоря Сікорського» \\ м. Київ, Украӥна
}

Останні дослідження показали, що захворювання печінки прогресують у кількості та призводять до 2 мільйонів смертей на рік у світі: 1 мільйон через ускладнення цирозу та 1 мільйон через вірусний гепатит та гепатоцелюлярну карциному [1]. Шляхи подолання проблеми, лежать не тільки у вдосконаленні методів лікування, а також у застосуванні сучасних методів діагностування захворювань печінки. Для визначення стану печінки, поширено використання в основному двух методів: біопсія (інвазивний) та ультразвукове дослідження (неінвазивний). Біопсія заключається у заборі зразків печінки пацієнта, тому надає більш точні результати, точність обмежуєтся кількістью проколів печінки. Однак внаслідок інвазивного втручання, пацієнту потрібен суттевий період відновлення. Також процедура може призвести до ускладнень або навіть до летальних наслідків. Ультразвукове дослідження (УЗД) не має таких побічних ефектів, але програє в точності 
діагностування. Саме тому покращення механізмів застосування неінвазивних методів діагностики $є$ актуальною задачею дослідження.

Для визначення ступеню фіброзу чи стану норма-патологія печінки лікарі керуються знімками УЗД-апарату як правило з лінійним чи конвексним датчиком. На рис. 1. позначено «області інтересу» УЗ зображення, що виділено та аналізуются спеціалістом. Вони ж стають предметом аналізу різноманітними алгоритмами для побудови класифікаторів та підготовки інформації для підтримки діагностичних рішень.

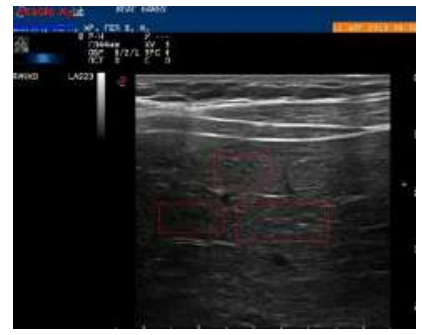

\section{Рис. 1. УЗД-знімок печінки з виділеними областями інтересу}

На рис. 2 наведено УЗД зображення норми та один з прикладів патології (дифузне захворювання) печінки. Кваліфіковане око спеціаліста відрізняе класи, та може наближено визначити ступінь патологічних змін в структурі печінки.
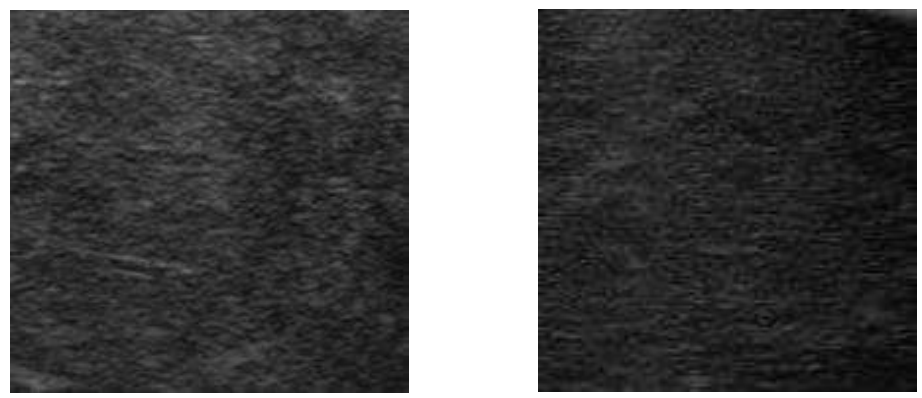

Рис. 2. Зображення патології печінки (зліва) та норми (справа)

Проте в умовах неперервного скринінгу та втоми лікаря починає грати суттєву роль людський фактор та зростає імовірність помилки діагностичного висновку. Тому стає доцільним режим контрольованого прийняття діагностичних рішень за рахунок застосування систем 64 
автоматизованної классифікації. 3 рисунку видно, що зображення норми має більш рівномірну та зернисту структуру, що дає можливість використання різних підходів текстурного аналізу для визначення та формалізації різниці в зображеннях для класифікації нормапатологія печінки. Дані для аналізу було надано інститутом ядерної медицини і променевої діагностики НАМН України. Всього оброблено 128 зображень, з них 56 - патологія, 72 - норма. УЗД знімки виконано за допомогою лінійного датчика.

В даній роботі запропоновано застосувати розроблений авторами аппарат класифікації об'єктів, заданих множинами спостережень [2,3] для класифікації зображень. Метод було розроблено для побудови структур (методом групового урахування аргументів МГУА) моделей об'єктів класифікаціi $\mathrm{d}_{\mathrm{j},} \mathrm{j}=1, \ldots, \mathrm{n}$, спостереження за якими виконувалися у часі. Моделі знаходилися як співвідношення з функціями запізнення виду

$$
y_{+P}=\mathrm{F}\left(y_{k_{l}}, y_{k_{2}}, \ldots, y_{k_{\mathrm{M}}}\right)=\sum_{i=1}^{m} a_{i} \phi_{i}(\mathbf{y}),
$$

де $P$ - інтервал прогнозу, $k_{i}$ - індекси запізнення змінної $y$, при яких $y$ найбільше корелює з прогнозованою величиною $y, \mathbf{y}-$ вектор $\left(y_{k_{1}}, y_{k_{2}}, \ldots, y_{k_{\mathrm{M}}}\right)^{\mathrm{T}}$

Метод розшукує єдину найкращу структуру, яка найточніше представить всі об'єкти класифікаціi $\mathrm{d}_{j,} j=1, \ldots, n$ за рахунок вектора параметрів $\mathrm{a}_{\mathrm{j}}, j=1, \ldots, m$ моделі (1). Коли для кожного об'єкту визначено його вектор параметрів $\mathrm{a}_{\mathrm{j}}, j=1, \ldots, m$ класифікацію об'єктів $\mathrm{d}_{j}$ м реалізують у просторі параметрів $a_{j}$.

У випадку зображень, роль незалежної змінної часу буде грати ряд номерів пікселю у лінійній розгортці зображення, залежної - відтінки сірого. Області інтересу розглядаються у просторі запізнень на лінійній розгортці, де розгортка, це послідовність рядків пікселів зображення, а простір запізнень - це значення $m$ піків функції автокореляції розгортки.

Всього було оброблено 128 зображень, з них 56 - патологія, 72 норма. УЗД знімки зроблено за допомогою лінійного датчика. В результаті застосування алгоритму найкращою структурою виявилася лінійна по запізненням структура виду

$$
y_{+1}=a_{0}+\sum_{i=1}^{4} a_{i} y_{1-\mathrm{i}}
$$


На рис. 4 наведений приклад оригінального зображення (клас - патологія) та його реконструкції за типом моделі (2). Якість реконструкції дає підстави вважати, що модель коректно відображає текстуру.
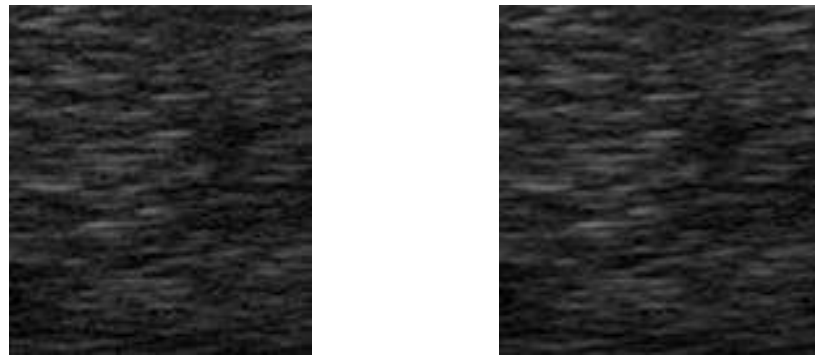

\section{Рис. 3. Зліва реконструкція патології, справа, оригінальне зображення}

Після відображення зображень у простір параметрів регресій структури (2) задача класифікації у просторі запізнень стає можливою для застосування будь-якого стандартного алгоритму класифікації. У даній роботі для цього використовується алгоритм-ансамбль «Випадковий Ліс» (Random forest) [4]. Результати роботи цього алгоритму наведені нижче у таблиці:

Таблиця 1

Результати класифікації зображень печінки за множиною регресій

\begin{tabular}{|c|c|c|c|}
\hline & Точність & Повнота & $\mathrm{F} 1$ \\
\hline Норма/Патологія & 0.72 & 0.91 & 0.81 \\
\hline
\end{tabular}

Для характеристики ефективності алгоритму використовувались показники «точність» та «повнота», а також гармонічне середне F1-міра.

Висновки

Якість реконструкція УЗ зображень печінки за одержаними моделями регресій у просторі запізнень по розгортці області інтересу дає підстави вважати застосування пропонованого підходу для опису об'єктів даного класу можливим. Результати класифікації нормапатологія печінки дозволяють стверджувати, що застосування розробленого авторами методу класифікації об'єктів заданих множинами спостережень для класифікації УЗ зображень печінки у поєднанні 3 іншими ознаками текстури $є$ перпективним. 


\title{
Література:
}

1. Sumeet K Asrani, Harshad Devarbhavi, John Eaton, Patrick S Kamath. Burden of liver diseases in the world. 2018. C. 1.

2. Грішко Д. Ю. Трофименко О.В. Павлов О.В. Структурний синтез за критерієм точності в задачі класифікації об'єктів множин. 2019.

3. Ievgen Arnoldovich Nastenko, Oleksandra Olegivna Konoval, Olena Konstantinovna Nosovets, Volodymyr Anatolevich Pavlov. Set Classification. Ch.3 In: Techno-Social Systems for Modern Economical and Governmental Infrastructures (Advances in Finance, Accounting, and Economics), pp. 44-83. 2018

4. Tin Kam Ho. Random Decision Forests. 2011.

DOI https://doi.org/10.30525/978-9934-588-79-2-1.16

\section{МОДЕЛЬ ВИБОРУ SСАDА-СИСТЕМИ ДЛЯ АВТОМАТИЗАЦЇ ПРОЦЕСУ ДОЗУВАННЯ РІДИНИ}

\author{
Петренко Ю. А. \\ доктор технічних наук, професор, \\ професор кафедри автоматизачіі \\ та комп'ютерно-інтегрованих технологій
}

Харківського національного автомобільно-дорожнього університету

Костиря Д. А.

студентка механічного факультету

Харківського національного автомобільно-дорожнього університету

Аширов Д. В.

студент механічного факультету

Харківського начіонального автомобільно-дорожнього університету

Комп'ютерна технологія вибору програмних засобів для авторизації системи дозування рідини дозволяє зменшити витрати на персонал, отже підвищуються економічні показники, а також підвищити ефективність дозування рідини за рахунок розробки системи диспетчерського управління на підставі SCADA-систем.

Система автоматизації керування призначена для рішення загальної задачі створення ефективного механізму керування ТП. У зв’язку 3 цим, першим етапом при впровадженні системи $є$ перед проектне обстеження діяльності ТП. Виконується системний аналіз діяльності ТП. Під перед проектним обстеженням розуміється процес збору інформації про структуру і діяльність ТП. Зібрана інформація прохо- 